\title{
Adipose Tissue as an Endocrine Organ
}

\author{
ERIN E. KERSHAW AND JEFFREY S. FLIER
}

Division of Endocrinology, Department of Medicine, Beth Israel Deaconess Medical Center, Boston, Massachusetts 02215

\begin{abstract}
Adipose tissue is a complex, essential, and highly active metabolic and endocrine organ. Besides adipocytes, adipose tissue contains connective tissue matrix, nerve tissue, stromovascular cells, and immune cells. Together these components function as an integrated unit. Adipose tissue not only responds to afferent signals from traditional hormone systems and the central nervous system but also expresses and secretes factors with important endocrine functions. These factors include leptin, other cytokines, adiponectin, complement components, plasminogen activator inhibitor-1, proteins of
\end{abstract}

the renin-angiotensin system, and resistin. Adipose tissue is also a major site for metabolism of sex steroids and glucocorticoids. The important endocrine function of adipose tissue is emphasized by the adverse metabolic consequences of both adipose tissue excess and deficiency. $A$ better understanding of the endocrine function of adipose tissue will likely lead to more rational therapy for these increasingly prevalent disorders. This review presents an overview of the endocrine functions of adipose tissue. (J Clin Endocrinol Metab 89: 2548-2556, 2004)
$\mathrm{T}$ HE TRADITIONAL VIEW of adipose tissue as a passive reservoir for energy storage is no longer valid. As early as 1987, adipose tissue was identified as a major site for metabolism of sex steroids (1) and production of adipsin, an endocrine factor that is markedly down-regulated in rodent obesity (2). The subsequent identification and characterization of leptin in 1994 firmly established adipose tissue as an endocrine organ (3). Adipose tissue is now known to express and secrete a variety of bioactive peptides, known as adipokines, which act at both the local (autocrine/paracrine) and systemic (endocrine) level (Table 1). In addition to these efferent signals, adipose tissue expresses numerous receptors that allow it to respond to afferent signals from traditional hormone systems as well as the central nervous system (CNS) (Table 2). Thus, besides the biological repertoire necessary for storing and releasing energy, adipose tissue contains the metabolic machinery to permit communication with distant organs including the CNS. Through this interactive network, adipose tissue is integrally involved in coordinating a variety of biological processes including energy metabolism, neuroendocrine function, and immune function.

The important endocrine function of adipose tissue is emphasized by the adverse metabolic consequences of both adipose tissue excess and deficiency. Adipose tissue excess or obesity, particularly in the visceral compartment, is associated with insulin resistance, hyperglycemia, dyslipidemia, hypertension, and prothrombotic and proinflammatory

Abbreviations: ACE, Angiotensin-converting enzyme; AdipoR, adiponectin receptor; AGT, angiotensinogen; ASP, acylating simulation protein; AT1, angiotensin II receptor type I; CNS, central nervous system; HPA, hypothalamic-pituitary-adrenal; HSD, hydroxysteroid dehydrogenase; $11 \beta \mathrm{HSD} 1,11 \beta$-hydroxysteroid dehydrogenase type 1 ; IL6R, IL-6 receptor; MCP, monocyte chemotactic protein; NEFA, nonesterified fatty acid; PAI, plasminogen activator inhibitor; RAS, renin angiotensin system; SNS, sympathetic nervous system; TZD, thiazoladinedione.

JCEM is published monthly by The Endocrine Society (http://www. endo-society.org), the foremost professional society serving the endocrine community. states (4). The prevalence of obesity and these associated morbidities, known as the metabolic syndrome, has reached epidemic proportions (4). Interestingly, adipose tissue deficiency or lipodystrophy is also associated with features of the metabolic syndrome in both humans and rodents (5). Furthermore, the prevalence of lipodystrophy in humans is increasing with the use of highly active antiretroviral therapy for HIV (5). Thus, both excess and deficiency of adipose tissue have harmful metabolic consequences and represent significant medical and socioeconomic burdens in the world today.

It is now clear that adipose tissue is a complex and highly active metabolic and endocrine organ $(6,7)$. Besides adipocytes, adipose tissue contains connective tissue matrix, nerve tissue, stromovascular cells, and immune cells (8). Although adipocytes express and secrete several endocrine hormones such as leptin and adiponectin, many secreted proteins are derived from the nonadipocyte fraction of adipose tissue (9). Regardless, these components function as an integrated unit, making adipose tissue a true endocrine organ (8). Here we present an overview of the endocrine functions of adipose tissue. These functions fall into two broad categories: 1) secreted proteins that have metabolic effects on distant cells or tissues, and 2) enzymes involved in the metabolism of steroid hormones.

\section{Adipose Tissue-Secreted Proteins}

\section{Leptin}

Before the identification of leptin, parabiosis studies in mice carrying the recessive mutations, obese $(o b)$ and diabetes $(d b)$, predicted the existence of a circulating endocrine hormone capable of communicating information from the periphery to the CNS with regard to the sufficiency of energy stores (10). These predictions were subsequently confirmed by the identification of the leptin gene (Lep $\left.{ }^{\text {ob }}\right)$ in 1994 (3) and its cognate receptor in 1995 and 1996 (Lepr $^{\mathrm{db}}$, Lepr $\left.{ }^{\mathrm{fa}}\right)$ (11-13). Leptin (from the Greek leptos, meaning thin) is a $16-\mathrm{kDa}$ polypeptide containing 167 amino acids with structural ho- 
TABLE 1. Examples of adipocyte-derived proteins with endocrine functions

\begin{tabular}{ll}
\hline Cytokines and cytokine- & Leptin \\
related proteins & TNF $\alpha$ \\
& IL-6 \\
Other immune-related & MCP-1 \\
proteins & \\
Proteins involved in the & PAI-1 \\
fibrinolytic system & Tissue factor \\
Complement and & Adipsin (complement \\
complement-related & factor D) \\
proteins & Complement factor B \\
& ASP \\
& Adiponectin \\
Lipids and proteins for lipid & Lipoprotein lipase (LPL) \\
metabolism or transport & Cholesterol ester transfer \\
& protein (CETP) \\
& Apolipoprotein E \\
NEFAs \\
Enzymes involved in steroid & Cytochrome P450- \\
metabolism & dependent aromatase \\
& $17 \beta$ HSD \\
Proteins of the RAS & $11 \beta$ HSD1 \\
Other proteins & AGT \\
\hline
\end{tabular}

TABLE 2. Examples of receptors expressed in adipose tissue

\begin{tabular}{cl} 
Receptors for traditional & Insulin receptor \\
endocrine hormones & Glucagon receptor \\
& GH receptor \\
& TSH receptor \\
& Gastrin/CCK-B receptor \\
& Glucagon like peptide-1 \\
& receptor \\
& Angiotensin II receptors \\
type 1 and 2 \\
Glucocorticoid receptor \\
Vuclear hormone receptors & Thyroid hormone \\
& receptor \\
& Androgen receptor \\
& Estrogen receptor \\
& Progesterone receptor \\
& Leptin receptor \\
Cy-6 receptor \\
TNF $\alpha$ receptor \\
Catecholamine receptors & $\beta 1, \beta 2, \beta 3$ receptors \\
& $\alpha 1, \alpha 2$ receptors \\
\hline
\end{tabular}

mology to cytokines. Adipocytes secrete leptin in direct proportion to adipose tissue mass as well as nutritional status, and this secretion is greater from sc relative to visceral adipose tissue $(9,14)$. Leptin expression and secretion are also regulated by a variety of other factors. For example, leptin is increased by insulin, glucocorticoids, TNF $\alpha$, estrogens, and CCAAT/enhancer-binding protein- $\alpha$ and decreased by $\beta 3$ adrenergic activity, androgens, free fatty acids, GH, and peroxisome proliferator-activated receptor- $\gamma$ agonists (15). Leptin receptors are members of the cytokine receptor class I superfamily and are expressed in both the CNS and periphery (16). Although several splice variants of the leptin receptor have been identified, the long form mediates the majority of leptin's myriad effects (16).

The effects of leptin on energy homeostasis are well documented (17). Many of these effects, particularly on energy intake and expenditure, are mediated via hypothalamic pathways, whereas other effects are mediated via direct action on peripheral tissues including muscle and pancreatic $\beta$-cells (16). Although initially viewed as an antiobesity hormone, leptin's primary role is to serve as a metabolic signal of energy sufficiency rather than excess (18). Leptin levels rapidly decline with caloric restriction and weight loss. This decline is associated with adaptive physiological responses to starvation including increased appetite and decreased energy expenditure. These same responses are observed in leptin-deficient mice and humans, despite massive obesity. Furthermore, these responses are readily normalized by lowdose leptin replacement. In contrast, common forms of obesity are characterized by elevated circulating leptin. Neither endogenously high leptin levels nor treatment with exogenous leptin is effective in ameliorating this obesity, consistent with a state of leptin resistance $(16,19)$. The mechanism for leptin resistance is unknown but may result from defects in leptin signaling or transport across the blood-brain barrier $(16,19)$. Clearly, the most sensitive portion of the leptin dose-response curve resides in the physiological range between the low levels induced by food restriction and the rising levels induced by refeeding and not in the supraphysiological range associated with obesity. This role of leptin as an indicator of energy sufficiency makes sense from an evolutionary perspective but provides no consolation in our current environment of energy abundance.

In addition to its effects on energy homeostasis, leptin regulates neuroendocrine function and traditional endocrine systems. Leptin deficiency in Lep ${ }^{\mathrm{ob}} / \mathrm{Lep}^{\mathrm{ob}}$ mice is associated with activation of the hypothalamic-pituitary-adrenal (HPA) axis and suppression of the hypothalamic-pituitary-thyroid and -gonadal axes. Leptin decreases hypercortisolemia in $\mathrm{Lep}^{\mathrm{ob}} / \mathrm{Lep}^{\mathrm{ob}}$ mice, inhibits stress-induced secretion of hypothalamic CRH in mice, and inhibits cortisol secretion from rodent and human adrenocortical cells in vitro. The role of leptin in HPA activity in humans in vivo remains unclear. Leptin also normalizes suppressed thyroid hormone levels in leptin-deficient mice and humans, in part via stimulation of TRH expression and secretion from hypothalamic TRH neurons $(16,20)$. Leptin accelerates puberty in normal mice and restores normal gonadotropin secretion and reproductive function in leptin-deficient mice and humans (21). Leptin replacement during fasting prevents starvation-induced changes in the hypothalamic-pituitary-gonadal and -thyroid axes in healthy men (22). Leptin also has direct effects via peripheral leptin receptors in the ovary, testis, prostate, and placenta (15).

Several other important endocrine effects of leptin include regulation of immune function, hematopoiesis, angiogenesis, and bone development. Leptin normalizes the suppressed immune function associated with malnutrition and leptin deficiency (23). Leptin also promotes proliferation and differentiation of hematopoietic cells, alters cytokine production by immune cells, stimulates endothelial cell growth and angiogenesis, and accelerates wound healing (15). An important role for leptin in bone development is supported by the observation that leptin-deficient $\mathrm{Lep}^{\mathrm{ob}} /$ Lep $^{\mathrm{ob}}$ mice have increased bone mass, despite hypercortisolemia and hypogonadism (24). Chemical lesions of specific 
hypothalamic neurons suggest that the ventral medial hypothalamus (VMH) is involved in leptin's effect on bone mass (24). Leptin-responsive neurons in the VMH are known to influence sympathetic nervous system (SNS) activity. Indeed, mice with defective SNS activity due to absence of dopamine $\beta$-hydroxylase have high bone mass and are resistant to the antiosteogenic effects of leptin, whereas transgenic overexpression of leptin in osteoblasts has no effect on bone mass (24). These data suggest that leptin decreases bone mass indirectly via activation of the SNS (24). Leptin clearly has diverse endocrine function in addition to its effects on energy homeostasis. As a result, leptin is the prototype for all adipose tissue-derived endocrine hormones.

\section{$T N F \alpha$}

$\mathrm{TNF} \alpha$ is a cytokine initially described as an endotoxininduced factor causing necrosis of tumors and subsequently shown to be identical to cachexin, a factor secreted by macrophages in vitro (Ref. 25 and references therein). TNF $\alpha$ is a $26-\mathrm{kDa}$ transmembrane protein that is cleaved into a $17-\mathrm{kDa}$ biologically active protein that exerts its effects via type I and type II TNF $\alpha$ receptors. Within adipose tissue, TNF $\alpha$ is expressed by adipocytes and stromovascular cells (9). TNF $\alpha$ expression is greater in sc compared with visceral adipose tissue, but this finding may be dependent on total and regional fat mass $(9,14)$. Adipocytes also express both types of $\mathrm{TNF} \alpha$ receptors as membrane bound and soluble forms (25). The ability of TNF $\alpha$ to induce cachexia in vivo naturally led to an extensive evaluation of its role in energy homeostasis.

Although initially suspected of playing a role in cachexia, TNF $\alpha$ has now been implicated in the pathogenesis of obesity and insulin resistance (25-27). Adipose tissue expression of $\mathrm{TNF} \alpha$ is increased in obese rodents and humans and is positively correlated with adiposity and insulin resistance (2528). Although circulating concentrations of $\mathrm{TNF} \alpha$ are low relative to local tissue concentrations, plasma $\mathrm{TNF} \alpha$ levels have been positively correlated with obesity and insulin resistance in some studies but not others (28). Chronic exposure to TNF $\alpha$ induces insulin resistance both in vitro and in vivo (25). Treatment with neutralizing soluble $\mathrm{TNF} \alpha$ receptors improves insulin sensitivity in rodent obesity but not in humans (25). Targeted gene deletion of TNF $\alpha$ or its receptors significantly improves insulin sensitivity and circulating nonesterified fatty acids (NEFAs) in rodent obesity (29).

Several potential mechanisms for TNF $\alpha$ 's metabolic effects have been described. First, TNF $\alpha$ influences gene expression in metabolically important tissues such as adipose tissue and liver (30). In adipose tissue, TNF $\alpha$ represses genes involved in uptake and storage of NEFAs and glucose, suppresses genes for transcription factors involved in adipogenesis and lipogenesis, and changes expression of several adipocytesecreted factors including adiponectin and IL-6 (30). In liver, TNF $\alpha$ suppresses expression of genes involved in glucose uptake and metabolism and fatty acid oxidation and increases expression of genes involved in de novo synthesis of cholesterol and fatty acids (30). Second, TNF $\alpha$ impairs insulin signaling. This effect is mediated by activation of serine kinases that increase serine phosphorylation of insulin receptor substrate-1 and -2 , making them poor substrates for insulin receptor kinases and increasing their degradation (26). TNF $\alpha$ also impairs insulin signaling indirectly by increasing serum NEFAs, which have independently been shown to induce insulin resistance in multiple tissues (25). Thus, whereas TNF $\alpha$ clearly affects multiple metabolic processes, the relative contribution of direct endocrine effects may be less significant than the indirect effects resulting from autocrine or paracrine modulation of NEFAs or other adipose tissue-derived hormones.

\section{$I L-6$}

IL-6 is another cytokine associated with obesity and insulin resistance (28). IL-6 circulates in multiple glycosylated forms ranging from 22 to $27 \mathrm{kDa}$ in size. The IL-6 receptor (IL-6R) is homologous to the leptin receptor and exists as both an approximately $80-\mathrm{kDa}$ membrane-bound form and an approximately 50-kDa soluble forms. A complex consisting of the ligand-bound receptor and two homodimerized transmembrane gp130 molecules triggers intracellular signaling by IL-6. Within adipose tissue, IL-6 and IL-6R are expressed by adipocytes and adipose tissue matrix (9). Expression and secretion of IL-6 are 2 to 3 times greater in visceral relative to sc adipose tissue $(9,14)$. In contrast to TNF $\alpha$, IL- 6 circulates at high levels in the bloodstream, and as much as one third of circulating IL-6 originates from adipose tissue (28).

Adipose tissue IL-6 expression and circulating IL-6 concentrations are positively correlated with obesity, impaired glucose tolerance, and insulin resistance (28). Both expression and circulating levels decrease with weight loss (28). Furthermore, plasma IL-6 concentrations predict the development of type 2 diabetes and cardiovascular disease (28). Genetic polymorphisms of the IL-6 locus have been linked to obesity, energy expenditure, insulin sensitivity, and type 2 diabetes (28). Furthermore, peripheral administration of IL-6 induces hyperlipidemia, hyperglycemia, and insulin resistance in rodents and humans (28). IL-6 also decreases insulin signaling in peripheral tissues by reducing expression of insulin receptor signaling components and inducing suppressor of cytokine signaling 3 , a negative regulator of both leptin and insulin signaling (31). IL-6 also inhibits adipogenesis and decreases adiponectin secretion (28). These peripheral effects of IL-6 are consistent with the above epidemiological findings, suggesting a causal role for IL-6 in obesity and insulin resistance.

Evaluation of the central role of IL-6, however, suggests a more complex role for IL-6 in energy homeostasis. IL-6 levels in the CNS are negatively correlated with fat mass in overweight humans, suggesting central IL-6 deficiency in obesity. Central administration of IL-6 increases energy expenditure and decreases body fat in rodents. Furthermore, transgenic mice overexpressing IL-6 have a generalized defect in growth, which includes reduced body weight and decreased fat pad weights (32). On the other hand, mice with a targeted deletion of IL-6 develop mature-onset obesity and associated metabolic abnormalities, which are reversed by IL-6 replacement, suggesting that IL- 6 is involved in preventing rather than causing these conditions (33). Hence, IL-6 has different effects on energy homeostasis in the periphery and the CNS. 


\section{Macrophages and monocyte chemoattractant protein $(M C P)-1$}

Obesity is associated with increased adipose tissue infiltration by macrophages $(34,34 a, 34 b)$. Activated macrophages secrete inflammatory factors that contribute to insulin resistance, including TNF $\alpha$ and IL-6. MCP-1, a chemokine that recruits monocytes to sites of inflammation, is expressed and secreted by adipose tissue (34). Whereas the cellular source of MCP-1 expression is unclear, both adipocytes and stromovascular cells have been implicated (34). Adipose tissue expression of MCP-1 and circulating MCP-1 levels are increased in rodent obesity, suggesting that MCP-1mediated macrophage infiltration of adipose tissue may contribute to the metabolic abnormalities associated with obesity and insulin resistance $(35,36)$.

MCP-1 has local as well as endocrine effects. Incubation of cultured adipocytes with MCP-1 decreases insulin-stimulated glucose uptake and insulin-induced insulin receptor tyrosine phosphorylation, suggesting that MCP-1 directly contributes to adipose tissue insulin resistance $(36,37)$. MCP-1 also inhibits adipocyte growth and differentiation by decreasing the expression of a number of adipogenic genes $(36,37)$. Increased circulating MCP-1 in rodent obesity is associated with increased circulating monocytes (35). Peripheral administration of MCP-1 to mice increases circulating monocytes, promotes accumulation of monocytes in collateral arteries, and increases neointimal formation $(35,38)$. These findings support an endocrine function of MCP-1 and implicate it in the development of atherosclerosis.

\section{Plasminogen activator inhibitor (PAI)-1}

Several proteins of the hemostasis and fibrinolytic system are secreted by adipocytes including tissue factor and PAI-1 (39). PAI-1 is a member of the serine protease inhibitor family and is the primary inhibitor of fibrinolysis by inactivating urokinase-type and tissue-type plasminogen activator. PAI-1 has also been implicated in variety of other biological processes including angiogenesis and atherogenesis. PAI-1 is expressed by many cell types within adipose tissue including adipocytes (9). PAI-1 expression and secretion are greater in visceral relative to Sc adipose tissue $(9,14)$.

Plasma PAI-1 levels are elevated in obesity and insulin resistance, are positively correlated with features of the metabolic syndrome, and predict future risk for type 2 diabetes and cardiovascular disease $(39,40)$. Plasma PAI-1 levels are strongly associated with visceral adiposity, which is independent of other variables including insulin sensitivity, total adipose tissue mass, or age $(14,39)$. Weight loss and improvement in insulin sensitivity due to treatment with metformin or thiazoladinediones (TZDs) significantly reduce circulating PAI-1 levels (39). TNF $\alpha$ contributes to the elevated PAI-1 levels observed in obesity and insulin resistance $(9,39$, 40). Mice with targeted deletion in PAI-1 have decreased weight gain on high-fat diet, increased energy expenditure, improved glucose tolerance, and enhanced insulin sensitivity (41). Likewise, targeted deletion of PAI-1 in Lep ${ }^{\mathrm{ob}} / \mathrm{Lep}^{\mathrm{ob}}$ mice decreases adiposity and improves metabolic parameters (42). Thus, PAI-1 may contribute to the development of obesity and insulin resistance and may be a causal link between obesity and cardiovascular disease.

\section{Adiponectin}

Adiponectin was independently characterized in 1995 and 1996 by four groups using different methods, hence its alternative names of apM1 (adipose most abundant gene transcript 1), Acrp30 (adipocyte complement-related protein of $30 \mathrm{kDa}$ ), adipoQ, and GBP28 (gelatin binding protein of 28 $\mathrm{kDa})$ (43-46). Adiponectin is highly and specifically expressed in differentiated adipocytes and circulates at high levels in the bloodstream (47). Adiponectin expression is higher in sc than visceral adipose tissue (9). Adiponectin is an approximately $30-\mathrm{kDa}$ polypeptide containing an $\mathrm{N}$ terminal signal sequence, a variable domain, a collagen-like domain, and a C-terminal globular domain (43-46). It shares strong sequence homology with type VIII and X collagen and complement component C1q (43-46). Interestingly, the tertiary structure of the globular domain bears a striking similarity to TNF $\alpha$, despite a lack of homology in primary sequence (47). Posttranslational modification by hydroxylation and glycosylation produces multiple isoforms, which assemble into trimers and then into higher-order oligomeric structures (47). A proteolytic cleavage product containing the globular domain of adiponectin also circulates at physiologically significant levels and has biological activity (47).

Adiponectin receptors (AdipoR) 1 and 2 have been identified (48). The receptors contain seven-transmembrane domains but are structurally and functionally distinct from $G$ protein-coupled receptors. AdipoR1 is expressed primarily in muscle and functions as a high-affinity receptor for globular adiponectin and a low-affinity receptor for full-length adiponectin. AdipoR2 is expressed primarily in liver and functions as an intermediate-affinity receptor for both globular and full-length adiponectin. Thus, the biological effects of adiponectin depend on not only the relative circulating concentrations and properties of the different adiponectin isoforms but also the tissue-specific expression of the adiponectin receptor subtypes.

A strong and consistent inverse association between adiponectin and both insulin resistance and inflammatory states has been established $(47,49)$. Plasma adiponectin declines before the onset of obesity and insulin resistance in nonhuman primates, suggesting that hypoadiponectinemia contributes to the pathogenesis of these conditions (50). Adiponectin levels are low with insulin resistance due to either obesity or lipodystrophy, and administration of adiponectin improves metabolic parameters in these conditions $(47,49$, 51). Conversely, adiponectin levels increase when insulin sensitivity improves, as occurs after weight reduction or treatment with insulin-sensitizing drugs (47, 49). Furthermore, several polymorphisms in the adiponectin gene are associated with obesity and insulin resistance $(47,49)$. These epidemiological findings are corroborated by studies in murine models with altered adiponectin expression. Adiponectin-deficient mice develop premature diet-induced glucose intolerance and insulin resistance, increased serum NEFAs, and increased vascular neointimal smooth muscle proliferation in response to injury $(52,53)$. This unfavorable meta- 
bolic profile occurs without significant differences in body weight or food intake $(52,53)$. In contrast, transgenic overexpression of adiponectin in mice leads to improved insulin sensitivity, glucose tolerance, and serum NEFAs $(53,54)$.

Several mechanisms for adiponectin's metabolic effects have been described $(47,49)$. In the liver, adiponectin enhances insulin sensitivity, decreases influx of NEFAs, increases fatty acid oxidation, and reduces hepatic glucose output. In muscle, adiponectin stimulates glucose use and fatty acid oxidation. Within the vascular wall, adiponectin inhibits monocyte adhesion by decreasing expression of adhesion molecules, inhibits macrophage transformation to foam cells by inhibiting expression of scavenger receptors, and decreases proliferation of migrating smooth muscle cells in response to growth factors. In addition, adiponectin increases nitric oxide production in endothelial cells and stimulate angiogenesis. These effects are mediated via increased phosphorylation of the insulin receptor, activation of AMPactivated protein kinase, and modulation of the nuclear factor $\kappa \mathrm{B}$ pathway $(47,49)$. Taken together, these studies suggest that adiponectin is a unique adipocyte-derived hormone with antidiabetic, antiinflammatory, and antiatherogenic effects.

\section{Adipsin and acylation stimulating protein (ASP)}

Adipsin (complement factor D) is one of several adipose tissue-derived complement components that are required for the enzymatic production of ASP, a complement protein that affects both lipid and glucose metabolism (55). Although adipsin was initially shown to be decreased in rodent obesity (2), subsequent studies in humans indicate that both adipsin and ASP positively correlate with adiposity, insulin resistance, dyslipidemia, and cardiovascular disease (55). ASP influences lipid and glucose metabolism via several mechanisms (55). ASP promotes fatty acid uptake by increasing lipoprotein lipase activity, promotes triglyceride synthesis by increasing the activity of diacylglycerol acyltransferase, and decreases lipolysis and release of NEFAs from adipocytes (55). ASP also increases glucose transport in adipocytes by increasing the translocation of glucose transporters and enhances glucose-stimulated insulin secretion from pancreatic $\beta$-cells (55). Not surprisingly, mice with targeted deletion of complement protein C3 (obligate ASP-deficient) have delayed postprandial clearance of triglycerides and NEFAs. Despite delayed lipid clearance, these mice have decreased body weight and fat mass, improved steady-state serum lipid profiles, and improved glucose tolerance and insulin sensitivity (55). This improved metabolic profile is attributed in part to increased energy expenditure and fatty acid oxidation in liver and muscle (56). A G protein-coupled receptor for ASP, known as C5L2, has been identified and is expressed in adipocytes (57). These findings support an endocrine role for ASP and related complement components in metabolism.

\section{Resistin}

Resistin (resistance to insulin) is an approximately $12-\mathrm{kDa}$ polypeptide that belongs to a unique family of cysteine-rich C-terminal domain proteins called resistin-like molecules, which are identical to the found in inflammatory zone family, hence resistin's alternative name FIZZ3 (58). Resistin was initially identified in 2001 as a novel mRNA induced during adipocyte differentiation but down-regulated by TZDs in vitro and subsequently identified by other groups using independent methods (59-61). In vivo studies in rodents confirmed adipose tissue-specific expression of resistin and down-regulation by TZDs (59). Resistin expression is 15 -fold greater in visceral compared with sc adipose tissue in rodents (58).

Initial studies suggested that resistin had significant effects on insulin action, potentially linking obesity with insulin resistance (58). Treatment of cultured adipocytes with recombinant resistin impairs insulin-stimulated glucose uptake whereas antiresistin antibodies prevent this effect (59). Similarly, in vivo treatment with recombinant resistin in rodents induces insulin resistance, whereas immunoneutralization of resistin has the opposite effect (59). Serum resistin is also elevated in rodent obesity (59). Furthermore, infusion of resistin under euglycemic hyperinsulinemic conditions produces hepatic insulin resistance (62). Subsequent studies, however, have reported conflicting results including upregulation of resistin by TZDs and suppression rather than elevation of resistin in rodent obesity (58). In addition, human resistin shares only $64 \%$ homology with murine resistin and is expressed at very low levels in adipocytes (58). Finally, numerous epidemiological studies in humans have failed to provide a clear and consistent link between resistin expression in adipose tissue or circulating resistin levels and adiposity or insulin resistance (58).

Recently, mice with targeted deletion of resistin have provided insight into resistin's metabolic effects in rodents (63). Mice lacking resistin have similar body weight and fat mass as wild-type mice, even when challenged with a high-fat diet. Nevertheless, mice lacking resistin have significantly improved fasting blood glucose levels on chow diet and improved glucose tolerance on high-fat diet. Insulin sensitivity is unaffected. The observed improvement in glucose homeostasis in mice lacking resistin is associated with decreased hepatic gluconeogenesis. This effect is mediated at least in part via increased activity of AMP-activated protein kinase and decreased expression of gluconeogenic enzymes in the liver. Whereas these data support a role for resistin in glucose homeostasis during fasting in rodents, a similar role in humans remains to be determined.

\section{Proteins of the renin angiotensin system (RAS)}

Several proteins of the classic RAS are also produced in adipose tissue. These include renin, angiotensinogen (AGT), angiotensin I, angiotensin II, angiotensin receptors type I (AT1) and type 2 (AT2), angiotensin-converting enzyme (ACE), and other proteases capable of producing angiotensin II (chymase, cathepsins D and G, tonin) $(64,65)$. Expression of AGT, ACE, and AT1 receptors is higher in visceral compared with sc adipose tissue $(64,65)$. Angiotensin II mediates many of the well-documented effects of the RAS including increasing vascular tone, aldosterone secretion from the adrenal gland, and sodium and water reabsorption from the kidney, all of which contribute to blood pressure regulation. 
Thus, the adipose tissue RAS is a potential link between obesity and hypertension.

Plasma AGT, plasma renin activity, plasma ACE activity, and adipose tissue AGT expression are positively correlated with adiposity in humans $(64,65)$. Adipose tissue AGT expression is decreased by fasting and increased by refeeding, and these changes are accompanied by parallel changes in blood pressure $(64,65)$. Inhibition of the RAS, either by inhibition of ACE or antagonism of the AT1 receptor, decreases weight and improves insulin sensitivity in rodents $(64,65)$. Although several large randomized trials have shown that ACE inhibitors reduce the incidence of type 2 diabetes, a direct effect of RAS inhibition on insulin sensitivity in humans has been observed in some studies (66) but not others (67). Finally, genetic variation in components of the RAS has been associated with obesity in isolated populations $(64,65)$.

In addition to its well-known effects on blood pressure, the RAS influences adipose tissue development. Components of the RAS such as AGT and angiotensin II are induced during adipogenesis (64). Angiotensin II promotes adipocyte growth and differentiation, both directly by promoting lipogenesis and indirectly by stimulating prostaglandin synthesis (64). Angiotensin II from mature adipocytes, however, may inhibit further recruitment of preadipocytes (64). Angiotensin II binds receptors on not only adipocytes but also stromovascular cells and nerve terminals, thus affecting adipose tissue physiology by altering blood flow and SNS activity (64). Angiotensin II inhibits lipolysis, promotes lipogenesis, decreases insulin-dependent glucose uptake, and increases hepatic gluconeogenesis and glycogenolysis (64). Furthermore, the adipose tissue RAS regulates the expression of adipose tissue-derived endocrine factors including prostacyclin, nitric oxide, PAI-1, and leptin $(64,65)$.

Murine models of increased and decreased AGT expression support a causal role for the adipose tissue RAS in obesity and hypertension. Mice with targeted deletion of AGT have decreased blood pressure and adipose tissue mass (68), whereas mice with transgenic overexpression of AGT in adipose tissue have increased blood pressure and adipose tissue mass (69). In addition, mice with transgenic amplification of glucocorticoids due to overexpression $11 \beta$-hydroxysteroid dehydrogenase type 1 (11 $\beta$ HSD1) in adipose tissue develop hypertension associated with activation of the RAS including increased plasma AGT, angiotensin II, and aldosterone (70). This is not surprising because glucocorticoids are known to increase adipose tissue expression of AGT. Thus, adipocyte-derived components of the RAS may play important autocrine, paracrine, and endocrine roles in the pathogenesis of obesity, insulin resistance, and hypertension.

\section{Enzymes Involved in the Metabolism of Steroid Hormones}

\section{Enzymes involved in the metabolism of sex steroids}

Although the adrenal gland and gonads serve as the primary source of circulating steroid hormones, adipose tissue expresses a full arsenal of enzymes for activation, interconversion, and inactivation of steroid hormones $(71,72)$. Traditionally the primary determinants of steroid hormone action were thought to be circulating free steroid hormone concentrations and tissue-specific expression of steroid hormone receptors. An additional determinant of steroid hormone action is tissue-specific prereceptor steroid hormone metabolism. Several steroidogenic enzymes are expressed in adipose tissue including cytochrome P450-dependent aromatase, $3 \beta$-hydroxysteroid dehydrogenase (HSD), $3 \alpha \mathrm{HSD}$, $11 \beta \mathrm{HSD} 1,17 \beta \mathrm{HSD}, 7 \alpha$-hydroxylase, $17 \alpha$-hydroxylase, $5 \alpha$ reductase, and UDP-glucuronosyltransferase 2B15 (71, 72). Given the mass of adipose tissue, the relative contribution of adipose tissue to whole body steroid metabolism is quite significant, with adipose tissue contributing up to $100 \%$ of circulating estrogen in postmenopausal women and $50 \%$ of circulating testosterone in premenopausal women $(71,72)$.

The sexually dimorphic distribution of adipose tissue in humans has implicated sex steroids in the regulation of adiposity and body fat distribution. Premenopausal females tend to have increased lower body or sc adiposity, whereas males and postmenopausal females tend to have increased upper body or visceral adiposity. Whereas circulating sex steroids or differential steroid receptor expression may contribute to this sexual dimorphism, adipose tissue-specific sex steroid metabolism may also play a role. Cytochrome P450dependent aromatase and $17 \beta \mathrm{HSD}$ are two enzymes that are highly expressed in adipose tissue stromal cells and preadipocytes. Aromatase mediates the conversion of androgens to estrogens: androstenedione to estrone and testosterone to estradiol. $17 \beta \mathrm{HSD}$ mediates the conversion of weak androgens or estrogens to their more potent counterparts: androstenedione to testosterone and estrone to estradiol. Expression of $17 \beta \mathrm{HSD}$ is decreased relative to aromatase in sc adipose tissue but increased relative to aromatase in visceral adipose tissue $(71,72)$. The ratio of $17 \beta \mathrm{HSD}$ to aromatase is positively correlated with central adiposity, implicating increased local androgen production in visceral adipose tissue $(71,72)$. Furthermore, mice with targeted ablation of aromatase and humans with naturally occurring mutations in aromatase have increased visceral adiposity, insulin resistance, dyslipidemia, and hepatic steatosis (73-76). Thus, adipose tissue is an important site for both metabolism and secretion of sex steroids.

\section{Enzymes involved in the metabolism of glucocorticoids}

Attention has recently focused on adipose tissue-specific regulation of glucocorticoid metabolism $(77,78)$. This tissuespecific glucocorticoid metabolism is primarily determined by the enzyme $11 \beta \mathrm{HSD} 1$, which catalyzes the conversion of hormonally inactive $11 \beta$-ketoglucocorticoid metabolites (cortisone in humans and 11-dehydrocorticosterone in mice) to hormonally active $11 \beta$-hydroxylated metabolites (cortisol in humans and corticosterone in mice). 11ßHSD1 is highly expressed in adipose tissue, particularly in visceral adipose tissue $(77,78)$. Although $11 \beta$ HSD1 amplifies local glucocorticoid concentrations within adipose tissue, it does not contribute significantly to systemic glucocorticoid concentrations.

Tissue-specific dysregulation of glucocorticoid metabolism by $11 \beta \mathrm{HSD} 1$ has been implicated in a variety of common medical conditions including obesity, diabetes, hypertension, dyslipidemia, hypertension, cardiovascular disease, and polycystic ovarian syndrome $(77,78)$. 11ßHSD1 activity 
is reduced in liver and enhanced in visceral adipose tissue of leptin-resistant Lepr $^{\mathrm{fa}} /$ Lepr $^{\mathrm{fa}}$ rats and leptin-deficient Lep $^{\mathrm{ob}} /$ Lep $^{\mathrm{ob}}$ mice $(77,78)$. In human idiopathic obesity, $11 \beta$ HSD1 expression and activity are also decreased in liver and increased in adipose tissue and are highly correlated with total and regional adiposity $(77,78)$. Polymorphisms in the $11 \beta$ HSD1 gene have been linked to adiposity $(79,80)$. Finally, pharmacological inhibition of $11 \beta$ HSD1 in humans increases insulin sensitivity (81), suggesting a potential therapeutic role for $11 \beta$ HSD1 inhibition in the treatment of obesity and insulin resistance.

The importance of adipose tissue glucocorticoid metabolism by $11 \beta$ HSD1 is revealed by experiments in murine models of increased or decreased 11 $\beta$ HSD1 expression. Mice with transgenic overexpression of $11 \beta$ HSD1 in adipocytes have normal serum glucocorticoids and HPA axis function but have elevated local glucocorticoid concentrations in adipose tissue (82). These mice develop visceral obesity and features of the metabolic syndrome including insulin resistance, dyslipidemia, hypertension, and hepatic steatosis (82). In contrast, mice with targeted deletion of $11 \beta$ HSD1 in all tissues have a favorable metabolic phenotype characterized by decreased weight gain on high-fat diet, preferential fat deposition in the sc adipose tissue compartment, improved glucose tolerance and insulin sensitivity, and atheroprotective lipid profiles (83-85). These studies support a role for adipose tissue-specific glucocorticoid metabolism by $11 \beta$ HSD1 in the pathogenesis of visceral obesity and the metabolic syndrome.

\section{Depot-Specific Differences in the Endocrine Function of Adipose Tissue}

As a further level of complexity, there is considerable heterogeneity among the various adipose tissue depots. The sc and visceral adipose tissue depots have been the best characterized, particularly with respects to contribution to disease. Visceral adipose tissue is associated with increased risk for multiple medical morbidities including the metabolic syndrome. This observed difference in disease risk may be due to differences in endocrine function among adipose tissue depots. The anatomic location of each adipose tissue depot itself affects endocrine function. Endocrine hormones derived from visceral adipose tissue are secreted into the portal system and have direct access to the liver, whereas those derived from sc adipose tissue are secreted into the systemic circulation. Hence, the former have a relatively greater effect on hepatic metabolic function. In addition, adipose tissue depots exhibit unique adipokine expression and secretion profiles. For example, expression and secretion of IL-6 and PAI-1 are relatively greater in visceral adipose tissue, whereas leptin and adiponectin are greater in sc adipose tissue. Furthermore, adipose tissue depots also exhibit specific receptor expression patterns that influence their ability to respond to afferent signals. For example, expression of AT1, $\beta 3$-adrenergic, glucocorticoid, and androgen receptors are greater in visceral relative sc adipose tissue. Whereas the precise mechanisms for these differences are unclear, this functional heterogeneity among various adipose tissue depots suggests that adipose tissue may not simply be an en- docrine organ but perhaps a group of similar but unique endocrine organs.

\section{The Future of Adipose Tissue as an Endocrine Organ}

What is the future of adipose tissue as an endocrine organ? Several adipose tissue-derived hormones have been identified, but even those factors that are relatively well characterized, such as leptin, require further evaluation to more precisely define their physiological roles. In addition to known genes, as many as $40 \%$ of expressed genes in adipose tissue are novel genes, and $20-30 \%$ of these may be secreted proteins (86). The continued identification and characterization of these novel genes is likely to reveal further insight into the endocrine function of adipose tissue and the relationship between energy homeostasis and other physiological systems. Additional studies are also required to clarify the contribution of individual cellular components of adipose tissue to determine how these components function as a cohesive unit. Finally, understanding the endocrine function of adipose tissue will likely permit more rational approaches to treatment of the metabolic consequences of excess and deficiency of adipose tissue.

\section{Acknowledgments}

Received February 27, 2004. Accepted March 17, 2004

Address all correspondence and requests for reprints to: Erin E. Kershaw, M.D., or Jeffrey S. Flier, M.D., Division of Endocrinology, Department of Medicine, Beth Israel Deaconess Medical Center, 330 Brookline Avenue, Boston, Massachusetts 02215. E-mail: ekershaw@ bidmc.harvard.edu or jflier@bidmc.harvard.edu.

\section{References}

1. Siiteri PK 1987 Adipose tissue as a source of hormones. Am J Clin Nutr 45:277-282

2. Flier JS, Cook KS, Usher P, Spiegelman BM 1987 Severely impaired adipsin expression in genetic and acquired obesity. Science 237:405-408

3. Zhang Y, Proenca R, Maffei M, Barone M, Leopold L, Friedman JM 1994 Positional cloning of the mouse obese gene and its human homologue. Nature 372:425-432

4. Grundy SM, Brewer Jr HB, Cleeman JI, Smith Jr SC, Lenfant C 2004 Definition of metabolic syndrome: report of the National Heart, Lung, and Blood Institute/American Heart Association conference on scientific issues related to definition. Circulation 109:433-438

5. Leow MK, Addy CL, Mantzoros CS 2003 Clinical review 159: human immunodeficiency virus/highly active antiretroviral therapy-associated metabolic syndrome: clinical presentation, pathophysiology, and therapeutic strategies. J Clin Endocrinol Metab 88:1961-1976

6. Ahima RS, Flier JS 2000 Adipose tissue as an endocrine organ. Trends Endocrinol Metab 11:327-332

7. Fruhbeck G, Gomez-Ambrosi J, Muruzabal FJ, Burrell MA 2001 The adipocyte: a model for integration of endocrine and metabolic signaling in energy metabolism regulation. Am J Physiol Endocrinol Metab 280:E827-E847

8. Frayn KN, Karpe F, Fielding BA, Macdonald IA, Coppack SW 2003 Integrative physiology of human adipose tissue. Int J Obes Relat Metab Disord 27:875-888

9. Fain JN, Madan AK, Hiler ML, Cheema P, Bahouth SW 2004 Comparison of the release of adipokines by adipose tissue, adipose tissue matrix, and adipocytes from visceral and subcutaneous abdominal adipose tissues of obese humans. Endocrinology 145:2273-2282

10. Coleman DL 1973 Effects of parabiosis of obese with diabetes and normal mice. Diabetologia 9:294-298

11. Chen H, Charlat O, Tartaglia LA, Woolf EA, Weng X, Ellis SJ, Lakey ND, Culpepper J, Moore KJ, Breitbart RE, Duyk GM, Tepper RI, Morgenstern JP 1996 Evidence that the diabetes gene encodes the leptin receptor: identification of a mutation in the leptin receptor gene in $\mathrm{db} / \mathrm{db}$ mice. Cell 84:491-495

12. Lee GH, Proenca R, Montez JM, Carroll KM, Darvishzadeh JG, Lee JI, Friedman JM 1996 Abnormal splicing of the leptin receptor in diabetic mice. Nature 379:632-635

13. Tartaglia LA, Dembski M, Weng X, Deng N, Culpepper J, Devos R, Richards 
GJ, Campfield LA, Clark FT, Deeds J, et al 1995 Identification and expression cloning of a leptin receptor, OB-R. Cell 83:1263-1271

14. Wajchenberg BL 2000 Subcutaneous and visceral adipose tissue: their relation to the metabolic syndrome. Endocr Rev 21:697-738

15. Margetic S, Gazzola C, Pegg GG, Hill RA 2002 Leptin: a review of its peripheral actions and interactions. Int J Obes Relat Metab Disord 26:1407-1433

16. Bjorbaek C, Kahn BB 2004 Leptin signaling in the central nervous system and the periphery. Recent Prog Horm Res 59:305-331

17. Friedman JM, Halaas JL 1998 Leptin and the regulation of body weight in mammals. Nature 395:763-770

18. Flier JS 1998 Clinical review 94: what's in a name? In search of leptin's physiologic role. J Clin Endocrinol Metab 83:1407-1413

19. Flier JS 2004 Obesity wars: molecular progress confronts an expanding epidemic. Cell 116:337-350

20. Flier JS, Harris M, Hollenberg AN 2000 Leptin, nutrition, and the thyroid: the why, the wherefore, and the wiring. J Clin Invest 105:859-861

21. Hileman SM, Pierroz DD, Flier JS 2000 Leptin, nutrition, and reproduction: timing is everything. J Clin Endocrinol Metab 85:804-807

22. Chan JL, Heist K, DePaoli A, Veldhuis JD, Mantzoros CS 2003 The role of falling leptin levels in the neuroendocrine and metabolic adaptation to shortterm starvation in healthy men. J Clin Invest 111:1409-1421

23. Lord GM, Matarese G, Howard JK, Baker RJ, Bloom SR, Lechler RI 1998 Leptin modulates the $\mathrm{T}$-cell immune response and reverses starvation-induced immunosuppression. Nature 394:897-901

24. Cock TA, Auwerx J 2003 Leptin: cutting the fat off the bone. Lancet 362:15721574

25. Ruan H, Lodish HF 2003 Insulin resistance in adipose tissue: direct and indirect effects of tumor necrosis factor- $\alpha$. Cytokine Growth Factor Rev 14: 447-455

26. Hotamisligil GS 2003 Inflammatory pathways and insulin action. Int J Obes Relat Metab Disord 27(Suppl 3):S53-S55

27. Hotamisligil GS, Shargill NS, Spiegelman BM 1993 Adipose expression of tumor necrosis factor- $\alpha$ : direct role in obesity-linked insulin resistance. Science 259:87-91

28. Fernandez-Real JM, Ricart W 2003 Insulin resistance and chronic cardiovascular inflammatory syndrome. Endocr Rev 24:278-301

29. Uysal KT, Wiesbrock SM, Marino MW, Hotamisligil GS 1997 Protection from obesity-induced insulin resistance in mice lacking TNF- $\alpha$ function. Nature 389:610-614

30. Ruan H, Miles PD, Ladd CM, Ross K, Golub TR, Olefsky JM, Lodish HF 2002 Profiling gene transcription in vivo reveals adipose tissue as an immediate target of tumor necrosis factor- $\alpha$ : implications for insulin resistance. Diabetes 51:3176-3188

31. Senn JJ, Klover PJ, Nowak IA, Zimmers TA, Koniaris LG, Furlanetto RW, Mooney RA 2003 Suppressor of cytokine signaling-3 (SOCS-3), a potential mediator of interleukin-6-dependent insulin resistance in hepatocytes. J Biol Chem 278:13740-13746

32. De Benedetti F, Alonzi T, Moretta A, Lazzaro D, Costa P, Poli V, Martini A, Ciliberto G, Fattori E 1997 Interleukin 6 causes growth impairment in transgenic mice through a decrease in insulin-like growth factor-I. A model for stunted growth in children with chronic inflammation. J Clin Invest 99:643-650

33. Wallenius V, Wallenius K, Ahren B, Rudling M, Carlsten H, Dickson SL, Ohlsson C, Jansson JO 2002 Interleukin-6-deficient mice develop matureonset obesity. Nat Med 8:75-79

34. Wellen KE, Hotamisligil GS 2003 Obesity-induced inflammatory changes in adipose tissue. J Clin Invest 112:1785-1788

34a.Weisberg SP, McCann D, Desai M, Rosenbaum M, Leibel RL, Ferrante Jr AW 2003 Obesity is associated with macrophage accumulation in adipose tissue. J Clin Invest 112:1796-1808

34b.Xu H, Barnes GT, Yang Q, Tan G, Yang D, Chou CJ, Sole J, Nichols A, Ross JS, Tartaglia LA, Chen H 2003 Chronic inflammation in fat plays a crucial role in the development of obesity-related insulin resistance. J Clin Invest 112: 1821-1830

35. Takahashi K, Mizuarai S, Araki H, Mashiko S, Ishihara A, Kanatani A, Itadani H, Kotani H 2003 Adiposity elevates plasma MCP-1 levels leading to the increased CD11b-positive monocytes in mice. J Biol Chem 278:46654-46660

36. Sartipy P, Loskutoff DJ 2003 Monocyte chemoattractant protein 1 in obesity and insulin resistance. Proc Natl Acad Sci USA 100:7265-7270

37. Gerhardt CC, Romero IA, Cancello R, Camoin L, Strosberg AD 2001 Chemokines control fat accumulation and leptin secretion by cultured human adipocytes. Mol Cell Endocrinol 175:81-92

38. van Royen N, Hoefer I, Buschmann I, Kostin S, Voskuil M, Bode Ch, Schaper W, Piek JJ 2003 Effects of local MCP-1 protein therapy on the development of the collateral circulation and atherosclerosis in Watanabe hyperlipidemic rabbits. Cardiovasc Res 57:178-185

39. Mertens I, Van Gaal LF 2002 Obesity, haemostasis and the fibrinolytic system. Obes Rev 3:85-101

40. Juhan-Vague I, Alessi MC, Mavri A, Morange PE 2003 Plasminogen activator inhibitor-1, inflammation, obesity, insulin resistance and vascular risk. J Thromb Haemost 1:1575-1579

41. Ma LJ, Mao SL, Taylor KL, Kanjanabuch T, Guan Y, Zhang Y, Brown NJ, Swift LL, McGuinness OP, Wasserman DH, Vaughan DE, Fogo AB 2004
Prevention of obesity and insulin resistance in mice lacking plasminogen activator inhibitor 1. Diabetes 53:336-346

42. Schafer K, Fujisawa K, Konstantinides S, Loskutoff DJ 2001 Disruption of the plasminogen activator inhibitor 1 gene reduces the adiposity and improves the metabolic profile of genetically obese and diabetic ob/ob mice. FASEB J 15: 1840-1842

43. Maeda K, Okubo K, Shimomura I, Funahashi T, Matsuzawa Y, Matsubara K 1996 cDNA cloning and expression of a novel adipose specific collagen-like factor, apM1 (AdiPose Most abundant Gene transcript 1). Biochem Biophys Res Commun 221:286-289

44. Scherer PE, Williams S, Fogliano M, Baldini G, Lodish HF 1995 A novel serum protein similar to $\mathrm{C} 1 \mathrm{q}$, produced exclusively in adipocytes. J Biol Chem 270:26746-26749

45. Nakano Y, Tobe T, Choi-Miura NH, Mazda T, Tomita M 1996 Isolation and characterization of GBP28, a novel gelatin-binding protein purified from human plasma. J Biochem (Tokyo) 120:803-812

46. Hu E, Liang P, Spiegelman BM 1996 AdipoQ is a novel adipose-specific gene dysregulated in obesity. J Biol Chem 271:10697-10703

47. Chandran M, Phillips SA, Ciaraldi T, Henry RR 2003 Adiponectin: more than just another fat cell hormone? Diabetes Care 26:2442-2450

48. Yamauchi T, Kamon J, Ito Y, Tsuchida A, Yokomizo T, Kita S, Sugiyama T, Miyagishi M, Hara K, Tsunoda M, Murakami K, Ohteki T, Uchida S, Takekawa S, Waki H, Tsuno NH, Shibata Y, Terauchi Y, Froguel P, Tobe K, Koyasu S, Taira K, Kitamura T, Shimizu T, Nagai R, Kadowaki T 2003 Cloning of adiponectin receptors that mediate antidiabetic metabolic effects. Nature 423:762-769

49. Diez JJ, Iglesias P 2003 The role of the novel adipocyte-derived hormone adiponectin in human disease. Eur J Endocrinol 148:293-300

50. Hotta K, Funahashi T, Bodkin NL, Ortmeyer HK, Arita Y, Hansen BC, Matsuzawa Y 2001 Circulating concentrations of the adipocyte protein adiponectin are decreased in parallel with reduced insulin sensitivity during the progression to type 2 diabetes in rhesus monkeys. Diabetes 50:1126-1133

51. Kinlaw WB, Marsh B 2004 Adiponectin and HIV-lipodystrophy: taking HAART. Endocrinology 145:484-486

52. Kubota N, Terauchi Y, Yamauchi T, Kubota T, Moroi M, Matsui J, Eto K, Yamashita T, Kamon J, Satoh H, Yano W, Froguel P, Nagai R, Kimura S, Kadowaki T, Noda T 2002 Disruption of adiponectin causes insulin resistance and neointimal formation. J Biol Chem 277:25863-25866

53. Maeda N, Shimomura I, Kishida K, Nishizawa H, Matsuda M, Nagaretani H, Furuyama N, Kondo H, Takahashi M, Arita Y, Komuro R, Ouchi N, Kihara S, Tochino Y, Okutomi K, Horie M, Takeda S, Aoyama T, Funahashi T, Matsuzawa Y 2002 Diet-induced insulin resistance in mice lacking adiponectin/ACRP30. Nat Med 8:731-737

54. Combs TP, Pajvani UB, Berg AH, Lin Y, Jelicks LA, Laplante M, Nawrocki AR, Rajala MW, Parlow AF, Cheeseboro L, Ding YY, Russell RG, Lindemann D, Hartley A, Baker GR, Obici S, Deshaies Y, Ludgate M, Rossetti L, Scherer PE 2004 A transgenic mouse with a deletion in the collagenous domain of adiponectin displays elevated circulating adiponectin and improved insulin sensitivity. Endocrinology 145:367-383

55. Cianflone K, Xia Z, Chen LY 2003 Critical review of acylation-stimulating protein physiology in humans and rodents. Biochim Biophys Acta 1609:127143

56. Xia Z, Stanhope KL, Digitale E, Simion OM, Chen L, Havel P, Cianflone K 2004 Acylation-stimulating protein (ASP)/complement C3adesArg deficiency results in increased energy expenditure in mice. J Biol Chem 279:4051-4057

57. Kalant D, Cain SA, Maslowska M, Sniderman AD, Cianflone K, Monk PN 2003 The chemoattractant receptor-like protein C5L2 binds the C3a des-Arg77 / acylation-stimulating protein. J Biol Chem 278:11123-11129

58. Banerjee RR, Lazar MA 2003 Resistin: molecular history and prognosis. J Mol Med 81:218-226

59. Steppan CM, Bailey ST, Bhat S, Brown EJ, Banerjee RR, Wright CM, Patel HR, Ahima RS, Lazar MA 2001 The hormone resistin links obesity to diabetes. Nature 409:307-312

60. Kim KH, Lee K, Moon YS, Sul HS 2001 A cysteine-rich adipose tissue-specific secretory factor inhibits adipocyte differentiation. J Biol Chem 276:11252-11256

61. Holcomb IN, Kabakoff RC, Chan B, Baker TW, Gurney A, Henzel W, Nelson C, Lowman HB, Wright BD, Skelton NJ, Frantz GD, Tumas DB, Peale Jr FV, Shelton DL, Hebert CC 2000 FIZZ1, a novel cysteine-rich secreted protein associated with pulmonary inflammation, defines a new gene family. EMBO J 19:4046-4055

62. Rajala MW, Obici S, Scherer PE, Rossetti L 2003 Adipose-derived resistin and gut-derived resistin-like molecule- $\beta$ selectively impair insulin action on glucose production. J Clin Invest 111:225-230

63. Banerjee RR, Rangwala SM, Shapiro JS, Rich AS, Rhoades B, Qi Y, Wang J, Rajala MW, Pocai A, Scherer PE, Steppan CM, Ahima RS, Obici S, Rossetti L, Lazar MA 2004 Regulation of fasted blood glucose by resistin. Science 303:1195-1198

64. Engeli S, Schling P, Gorzelniak K, Boschmann M, Janke J, Ailhaud G, Teboul M, Massiera F, Sharma AM 2003 The adipose-tissue renin-angiotensin-aldosterone system: role in the metabolic syndrome? Int J Biochem Cell Biol 35:807-825

65. Goossens GH, Blaak EE, van Baak MA 2003 Possible involvement of the 
adipose tissue renin-angiotensin system in the pathophysiology of obesity and obesity-related disorders. Obes Rev 4:43-55

66. Pollare T, Lithell H, Berne C 1989 A comparison of the effects of hydrochlorothiazide and captopril on glucose and lipid metabolism in patients with hypertension. N Engl J Med 321:868-873

67. Petrie JR, Morris AD, Ueda S, Small M, Donnelly R, Connell JM, Elliott HL 2000 Trandolapril does not improve insulin sensitivity in patients with hypertension and type 2 diabetes: a double-blind, placebo-controlled crossover trial. J Clin Endocrinol Metab 85:1882-1889

68. Massiera F, Seydoux J, Geloen A, Quignard-Boulange A, Turban S, SaintMarc P, Fukamizu A, Negrel R, Ailhaud G, Teboul M 2001 Angiotensinogendeficient mice exhibit impairment of diet-induced weight gain with alteration in adipose tissue development and increased locomotor activity. Endocrinology 142:5220-5225

69. Massiera F, Bloch-Faure M, Ceiler D, Ceiler D, Murakami K, Fukamizu A Gasc JM, Quignard-Boulange A, Negrel R, Ailhaud G, Seydoux J, Meneton P, Teboul M 2001 Adipose angiotensinogen is involved in adipose tissue growth and blood pressure regulation. FASEB J 15:2727-2729

70. Masuzaki H, Yamamoto $\mathrm{H}$, Kenyon CJ, Elmquist JK, Morton NM, Paterson JM, Shinyama H, Sharp MG, Fleming S, Mullins JJ, Seckl JR, Flier JS 2003 Transgenic amplification of glucocorticoid action in adipose tissue causes high blood pressure in mice. J Clin Invest 112:83-90

71. Belanger C, Luu-The V, Dupont P, Tchernof A 2002 Adipose tissue intracrinology: potential importance of local androgen/estrogen metabolism in the regulation of adiposity. Horm Metab Res 34:737-745

72. Meseguer A, Puche C, Cabero A 2002 Sex steroid biosynthesis in white adipose tissue. Horm Metab Res 34:731-736

73. Jones ME, Thorburn AW, Britt KL, Hewitt KN, Misso ML, Wreford NG, Proietto J, Oz OK, Leury BJ, Robertson KM, Yao S, Simpson ER 2001 Aromatase-deficient (ArKO) mice accumulate excess adipose tissue. J Steroid Biochem Mol Biol 79:3-9

74. Jones ME, Thorburn AW, Britt KL, Hewitt KN, Wreford NG, Proietto J, Oz OK, Leury BJ, Robertson KM, Yao S, Simpson ER 2000 Aromatase-deficient (ArKO) mice have a phenotype of increased adiposity. Proc Natl Acad Sci USA 97:12735-12740

75. Misso ML, Murata Y, Boon WC, Jones ME, Britt KL, Simpson ER 2003 Cellular and molecular characterization of the adipose phenotype of the aromatase-deficient mouse. Endocrinology 144:1474-1480

76. Takeda K, Toda K, Saibara T, Nakagawa M, Saika K, Onishi T, Sugiura T, Shizuta Y 2003 Progressive development of insulin resistance phenotype in male mice with complete aromatase (CYP19) deficiency. J Endocrinol 176: 237-246

77. Stulnig TM, Waldhausl W $200411 \beta$-Hydroxysteroid dehydrogenase type 1 in obesity and type 2 diabetes. Diabetologia 47:1-11

78. Seckl JR, Walker BR 2001 Minireview: 11 $\beta$-hydroxysteroid dehydrogenase type 1-a tissue-specific amplifier of glucocorticoid action. Endocrinology 142: 1371-1376

79. Draper N, Echwald SM, Lavery GG, Walker EA, Fraser R, Davies E, Sorensen TI, Astrup A, Adamski J, Hewison M, Connell JM, Pedersen O, Stewart PM 2002 Association studies between microsatellite markers within the gene encoding human $11 \beta$-hydroxysteroid dehydrogenase type 1 and body mass index, waist to hip ratio, and glucocorticoid metabolism. J Clin Endocrinol Metab 87:4984-4990

80. Gelernter-Yaniv L, Feng N, Sebring NG, Hochberg Z, Yanovski JA 2003 Associations between a polymorphism in the $11 \beta$ hydroxysteroid dehydrogenase type I gene and body composition. Int J Obes Relat Metab Disord 27:983-986

81. Walker BR, Connacher AA, Lindsay RM, Webb DJ, Edwards CR 1995 Carbenoxolone increases hepatic insulin sensitivity in man: a novel role for 11oxosteroid reductase in enhancing glucocorticoid receptor activation. J Clin Endocrinol Metab 80:3155-3159

82. Masuzaki H, Paterson J, Shinyama H, Morton NM, Mullins JJ, Seckl JR, Flier JS 2001 A transgenic model of visceral obesity and the metabolic syndrome. Science 294:2166-2170

83. Kotelevtsev Y, Holmes MC, Burchell A, Houston PM, Schmoll D, Jamieson P, Best R, Brown R, Edwards CR, Seckl JR, Mullins JJ 1997 11 $\beta$-hydroxysteroid dehydrogenase type 1 knockout mice show attenuated glucocorticoidinducible responses and resist hyperglycemia on obesity or stress. Proc Natl Acad Sci USA 94:14924-14929

84. Morton NM, Holmes MC, Fievet C, Staels B, Tailleux A, Mullins JJ, Seckl JR 2001 Improved lipid and lipoprotein profile, hepatic insulin sensitivity, and glucose tolerance in $11 \beta$-hydroxysteroid dehydrogenase type 1 null mice. J Biol Chem 276:41293-41300

85. Morton NM, Paterson JM, Masuzaki H, Holmes MC, Staels B, Fievet C, Walker BR, Flier JS, Mullins JJ, Seckl JR 2004 Novel adipose tissue-mediated resistance to diet-induced visceral obesity in $11 \beta$-hydroxysteroid dehydrogenase type 1-deficient mice. Diabetes 53:931-938

86. Maeda K, Okubo K, Shimomura I, Mizuno K, Matsuzawa Y, Matsubara K 1997 Analysis of an expression profile of genes in the human adipose tissue. Gene 190:227-235

JCEM is published monthly by The Endocrine Society (http://www.endo-society.org), the foremost professional society serving the endocrine community. 